\title{
The effect of CTL learning model and learning style on the historical learning outcomes
}

\author{
Inda Syahra *, Sarkadi Sarkadi, Nurzengky Ibrahim \\ Universitas Negeri Jakarta. \\ Jl. Margonda Raya, RT 11/RW.14, Jakarta Timur, DKI Jakarta 13220, Indonesia. \\ indasyahra64@gmail.com \\ * Corresponding Author
}

\section{ARTICLE INFO}

\section{Article History}

Received:

21 January 2020;

Revised:

4 March 2020;

Accepted:

12 March 2020

\section{Keywords}

Historical learning

outcomes;

CTL learning models;

Learning styles

\begin{abstract}
This study aims to obtain the influence of learning models and learning styles on historical learning outcomes. Students are given a CTL and conventional learning model by measuring visual learning styles and auditory learning styles. This type of research is a quantitative study using an experimental method with a $2 \times 2$ factorial design. The population is all students of class $\mathrm{X}$ $2019 / 2020$ school year. The sampling technique used is multistage random sampling. Class X-A as an experimental class and grade X-B as a control class with a total of 70 students construct validity is analyzed by the correlation between items using Product Moment Correlation, and Cronbach's alpha formula tested reliability. The results showed that learning outcomes with the CTL learning model were higher than conventional learning models. While student learning outcomes using visual learning styles are more effective than auditory learning styles. There is a relationship between learning models with learning styles.
\end{abstract}

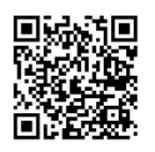

This is an open access article under the $\mathrm{CC}-\mathrm{BY}-\mathrm{SA}$ license.

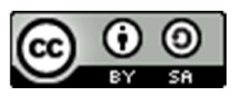

\section{INTRODUCTION}

In article 1 of Law Number 20, the year 2003 concerning the National Education System (UUSPN), it stated that the notion of education. That a conscious and planned effort to create an atmosphere of learning and learning process so that students actively develop their potential to have spiritual power, self-control, personality, intelligence, noble character, and the skills needed by themselves, society, nation, and country. The main theories referred to in this study are: 1.) Learning outcomes theory from Gagne (1975) which states that learning outcomes are a process of changing abilities reflected in behavior; 2.) Learning model theory from Dale (1966) which says that there is a relationship between visual media and learning outcomes; and 3.) Learning style theory from De Porter (2001) which divides a person's learning style in the visual, auditory, and kinesthetic fields. In essence, learning outcomes are a benchmark for achieving learning goals. Hamalik (2010, p. 15) states that learning objectives are several learning outcomes that show that students have done a learning activity, which generally includes new knowledge, skills, and attitudes, which expected to be achieved by students. It can conclude that the history of learning outcomes is a change in the competencies students have in learning history in the form of knowledge, skills, and attitudes. Learning outcomes are the final acquisition of the learning process. Good learning outcomes can reflect a good learning style because by knowing and understanding the learning styles that are best for it will help students in learning so that the results will be maximal. Many factors affect student learning outcomes in the learning process in class. It a teacher must improve student learning outcomes by 
knowing the student's learning style. Learning styles according to some experts can be classified into several models. Some learning style models are the type of Kolb's learning style, perceptual learning style and Myers Briggs Type Indicators learning style (Puji \& Ahmad, 2015 p. 225). Learning styles and learning outcomes of students are influenced by several factors, one of which is the interest or interest of students in learning. To improve learning outcomes and learning styles learning must be made interesting and fun. One factor of students' interest in learning is the approach factor. The learning approach is any means or strategy used to improve the effectiveness and efficiency of the process of learning certain material (Syah, 2011).

Historical learning outcomes obtained by students in learning influenced by two factors consist of internal and external factors. Internal factors are factors that originate from within students. External factors are factors that come from outside themselves students. One external factor that affects student learning outcomes is the learning model used by the teacher. DePorter and Hernacki (2002), from the results of his research, defines learning styles as learning habits that are loved by learners. Porter views teaching methods as a way for someone to accept, interact, and see their environment. Porter divides modality or learning styles into three groups, namely visual, auditory, and kinesthetic. According to the theory developed by DePorter and Hernacki, a person's learning style is part of an individual that is permanent at all times and is part of personality characteristics. Learning style or learning style, according to Keefe in Gufron \& Riswanita (2012), states that learning style is a cognitive characteristic, affective, and psychomotor behavior, as an indicator that acts relatively stable for students, so they feel inter-connected and react to the learning environment. Thus by observing that the conditions of the learning environment will shape one's learning style. Learning style is a consistent style practiced by a student in capturing stimulus or information, how to remember thinking, and solving problems. Learning styles are the preferred way by students in a learning process. With learning styles, students will more easily understand the lesson.

From the definition of the learning styles above, it can conclude that the learning style is fun. Learning process and is very liked by students in capturing stimulus and helping it in the learning process so that it can foster motivation in learning that is fun and maximum learning outcomes according to the desired needs. While one of the factors that come from within students (internal factors), namely learning styles are habits and ways that students like to receive and process information conveyed by the teacher. DePorter and Hernacki (2003, p. 110) state that learning styles are a combination of how to absorb, organize, and process information. Learning style is a tendency that is owned by students in understanding and processing the information presented by the teacher. Based on the above understanding, it can conclude that the learning style for each person is different, which is following the person's habits in absorbing, managing, and managing the information received. One internal factor is the learning style that can influence learning outcomes that are closely related to one's psychological or personal side. External factors are mainly due to the teacher's teaching methods that provide historical concepts as finished products to students. It means that there is no selection of processes and the use of various models in learning history. It is due to the lack of creative teachers in using the right model in history learning. Learning media, according to Sabri (2010, p. 10), is a tool used as an intermediary to convey messages and can stimulate students' thoughts, feelings, and progress so that they can encourage the learning process.

The Contextual Teaching and Learning (CTL) learning model, according to Johnson and Teachnet (2013, p. 176) is an educational process that aims to help students see meaning in academic material by linking academic lessons with the context of students 'daily lives, that is, in the context of students' social and cultural circumstances. According to Teachnet (2013), CTL teaching and learning helps us connect subject content with real situations and motivate students to make connections between knowledge and application in their daily lives. The CTL learning approach is a type of learning approach that links material and topics to real life. The way that can be done is by linking the material with factual conditions with examples, learning resources and learning media (Latipah \& Afriansyah, 2018 p. 4). The application of the CTL approach in learning will make learning more real to students. This will make learning more meaningful because students gain learning not only about knowledge in the classroom but also knowledge in the environment of daily life (Murtini, Fauzan \& Wulan, 2012). The meaning that can be obtained by students from learning related to what the meaning of learning, what are the benefits, what are the uses for their lives later 
(Sihono, 2004). To achieve meaningful learning can use the CTL approach. There are several components in the CTL approach, namely: constructivism, inquiry, questioning, modeling, reflection, and authentic assessment (Muhlisin, 2012).

The learning model that can use to help to learn outcomes effectively is the CTL learning model. The CTL learning model is student-oriented. According to Sanjaya (2007), that say Contextual Teaching and Learning (CTL) is a learning strategy that emphasizes the process of full student involvement to be able to find the material being studied and relate it to real-life situations. From some of the above understanding, it can conclude that contextual learning is a learning concept where the teacher brings the real world. That technique is into the classroom and encourages students to make connections between the knowledge they have and their application in their daily lives. While students acquire knowledge and skills from a limited context, little by little, and from the process, construct their own, as a provision to solve problems in their lives as members of the community. Contextual learning is teaching that allows students to strengthen, expand, and apply their academic knowledge and skills in a variety of settings in school and outside of school to solve real-world problems or simulated problems. Contextual learning occurs when students apply and experience what taught regarding real-world issues related to their roles and responsibilities as family members, citizens, students, and the workforce. Contextual learning is learning that occurs in close contact with experience.

By using the right model, the interaction of learning between teachers and students can increase, thereby affecting the amount of subject matter that can be absorbed by students, which in turn results from student learning increases. Associated with student learning styles are needed in designing or modifying the material, objectives, and models used. Through both learning styles and learning models that occur in the learning process, the possibility of student learning outcomes can achieving optimally. It shows that learning style is one of the variables of learning conditions that need to be considered by teachers in designing learning, especially in requiring individual learning styles. Based on the problems described in these problems, it can be concluded that the main purpose of this research is to prove the influence of learning methods on learning outcomes of historical subjects.

Student learning styles affect the learning outcomes. Based on relevant research conducted by Rahman and Yanti (2016) that there is a positive and significant influence on kinesthetic learning styles and visual learning styles on improving student learning outcomes. The results of an increase in learning styles are greater than those of students who use auditory learning styles. Other research conducted by Hartoto (2016) found that learning using the cooperative group type investigation method had a positive impact on improving the quality of learning history and student learning achievement. Subsequent research was conducted by Murtiani, Fauzan, \& Ratnawulan (2012) to determine the effectiveness of using the CTL approach to learning physics in Padang city junior high school. Based on these studies it was found that the use of the CTL approach was effective in improving the quality of physics learning. Research related to the contextual approach was also conducted by Kindarto \& Gafur (2014) in this study found that contextual learning with classroom action research strategies proved effective in increasing student learning activities.

\section{METHOD}

The research method used in this study is an experimental method with a two-way Analysis of Variance (ANOVA) 2 by two treatment level design. Researchers want to know the influence of learning models and student learning styles on student learning outcomes. McClave and Sincich $(2009$, p. 483) suggested that researchers designed an experiment by controlling specific treatments and placing experimental units for each treatment. The study consisted of two independent variables and one dependent vari-able. As the independent variable, 1 is the learning model (A) and as the separate variable two learn-ing styles (B). The dependent variable in this study is learning outcomes (Y). The independent vari-able 1 is the learning model, namely the CTL learning model (A1) and the conventional learning model (A2). In contrast, independent variable 2 is the visual learning style (B1) and the auditory learning style (B2). The population in this study were 175 class X students, divided into five classes. The sampling technique used is using a multistage random sampling 
technique by randomly taking two levels consisting of 70 students. The first step is giving treatment to the students who were in these two classes were given a questionnaire to get learning style score data. The procedure in this study was that the grade X-A class treated using the CTL learning model and the grade X-C class treated using a conventional learning model. Each treatment class divided into two learning styles, namely students who have a visual learning style and students who have an auditory learning style.

\section{FINDINGS AND DISCCUSIONS}

\section{Findings}

The data that will describe in this section are actual learning outcomes using the Contextual Teaching and Learning (CTL) learning model and historical learning outcomes scores using conventional learning models that categorized in visual learning styles and auditory learning styles. Learning outcomes of students who get treatment in using CTL learning models are higher than using conventional learning models. Student learning outcomes can see in groups of CTL learning models that use visual learning styles higher than students who use auditory learning styles. In this group, the CTL learning model, the average learning outcomes of students who use visual learning styles, are higher than those who use auditory learning styles. From the aspect of learning style, it appears that student learning outcomes in visual learning styles are higher than auditory learning styles. So it can be seen that the learning model, which uses learning styles in the CTL learning model group, gives an average learning out-come that is much higher than in the conventional learning model group. The average student learning outcomes using the auditory learning style in the CTL learning model group is higher than the auditory learning style in the conventional learning model group. The average learning outcomes of students who get treated using learning models and learning styles can see in the Table 1.

Table 1. Summary of History Learning Outcomes Scores

\begin{tabular}{cccc}
\hline $\begin{array}{c}\text { Learning media } \\
\text { Learning Style }\end{array}$ & CTL $\left(\mathrm{A}_{1}\right)$ & Conventional $\left(\mathrm{A}_{2}\right)$ & Total \\
\hline & $\mathrm{N}_{1}=15$ & $\mathrm{~N}_{2}=15$ & $\mathrm{~N}_{\mathrm{b} 1}=30$ \\
& $\sum \mathrm{X}_{1}=506$ & $\sum \mathrm{X}_{2}=377$ & $\sum \mathrm{X}_{\mathrm{b} 1}=883$ \\
Visual $\left(\mathrm{B}_{1}\right)$ & $\sum \mathrm{X}_{1}^{2}=17250$ & $\sum \mathrm{X}_{2}{ }^{2}=9737$ & $\sum \mathrm{X}_{\mathrm{b} 1}{ }^{2}=26987$ \\
& $\mathrm{X}_{1}=33,73$ & $\mathrm{X}_{2}=25,13$ & $\mathrm{X}_{\mathrm{b} 1}=29,43$ \\
& $\left(\sum \mathrm{X}_{1}\right)^{2}=256036$ & $\left(\sum \mathrm{X}_{2}\right)^{2}=142129$ & $\left(\sum \mathrm{X}_{\mathrm{b} 1}\right)^{2}=779689$ \\
& $\mathrm{~N}_{3}=15$ & $\mathrm{~N}_{4}=15$ & $\mathrm{~N}_{\mathrm{b} 2}=30$ \\
& $\sum \mathrm{X}_{3}=382$ & $\sum \mathrm{X}_{4}=435$ & $\sum \mathrm{X}_{\mathrm{b} 2}=817$ \\
$\sum \mathrm{X}_{3}^{2}=9942$ & $\sum \mathrm{X}_{4}^{2}=12815$ & $\sum \mathrm{X}_{\mathrm{b} 2}^{2}=22757$ \\
& $\mathrm{X}_{3}=25,47$ & $\mathrm{X}_{4}=29$ & $\mathrm{X}_{\mathrm{b} 2}=27,23$ \\
& $\left(\sum \mathrm{X}_{3}\right)^{2}=145924$ & $\left(\sum \mathrm{X}_{4}\right)^{2}=189225$ & $\left(\sum \mathrm{X}_{\mathrm{b} 2}\right)^{2}=667489$ \\
& $\mathrm{~N}_{\mathrm{k} 1}=30$ & $\mathrm{~N}_{\mathrm{k} 2}=30$ & $\mathrm{~N}_{\mathrm{bt}}=60$ \\
$\sum \mathrm{X}_{\mathrm{k} 1}=888$ & $\sum \mathrm{X}_{\mathrm{k} 2}=812$ & $\sum \mathrm{X}_{\mathrm{bt}}=1700$ \\
& $\sum \mathrm{X}_{\mathrm{k} 1}{ }^{2}=27192$ & $\sum \mathrm{X}_{\mathrm{k} 2}{ }^{2}=22552$ & $\sum \mathrm{X}_{\mathrm{bt}}{ }^{2}=49744$ \\
& $\mathrm{X}_{\mathrm{k} 1}=29,6$ & $\mathrm{X}_{\mathrm{k} 2}=27,07$ & $\mathrm{X}_{\mathrm{bt}}=28,33$ \\
& $\left(\sum \mathrm{X}_{\mathrm{k} 1}\right)^{2}=788544$ & $\left(\sum \mathrm{X}_{\mathrm{k} 2}\right)^{2}=659344$ & $\left(\sum \mathrm{X}_{\mathrm{bt}}\right)^{2}=2890000$ \\
\hline
\end{tabular}

Where hypothesis testing proper after the requirements for analysis testing met, the criteria for pre-analysis is by testing for normality and homogeneity. That hypothesis testing proper to check all the main results and the results of interactions on learning outcomes by using the results of twoway ANOVA analysis. 
Table 2. Summary of Normality Test Result (Liliefors) History Learning Outcomes Data

\begin{tabular}{ccccc}
\hline Group & $\mathrm{N}$ & $\mathrm{L}_{\text {hitung }}$ & $\mathrm{L}_{\text {tabel }}$ & Information \\
\hline $\mathrm{A}_{1}$ & 30 & 0,109 & 0,161 & Normal \\
$\mathrm{A}_{2}$ & 30 & 0,127 & 0,161 & Normal \\
$\mathrm{B}_{1}$ & 30 & 0,090 & 0,161 & Normal \\
$\mathrm{B}_{2}$ & 30 & 0,139 & 0,161 & Normal \\
$\mathrm{A}_{1} \mathrm{~B}_{1}$ & 15 & 0,173 & 0,220 & Normal \\
$\mathrm{A}_{1} \mathrm{~B}_{2}$ & 15 & 0,137 & 0,220 & Normal \\
$\mathrm{A}_{2} \mathrm{~B}_{1}$ & 15 & 0,146 & 0,220 & Normal \\
$\mathrm{A}_{2} \mathrm{~B}_{2}$ & 15 & 0,145 & 0,220 & Normal \\
\hline
\end{tabular}

Based on the Liliefors test, it found that the calculation results (L0) for all data groups were smaller than the Liliefors table value (Lt). Thus the sample group of this study came from populations that normally distributed so that normality requirements met. Normality testing carried out using the Barlett test at the significance level $\alpha=0.05$. A summary of the results of the homogeneity test variance of the treatment combination group can be seen in the Table 3 . Thus the variance of all treatment combinations is homogeneous, so homogeneity requirements are met. Then carried out further tests using the Tuckey test. A summary of the results of the two path analysis of variance analysis (ANAVA) is seen in the Table 4. A summary of the results of the two path analysis of variance analysis (ANAVA) is seen in the Table 5.

Table 3. Summary of Test Results for Homogeneity of Variance in Combined Treatment Groups

\begin{tabular}{ccccc}
\hline Group & Variance & $\mathrm{F}_{\text {hitung }}$ & $\mathrm{F}_{\text {tabel }}$ & Information \\
\hline $\mathrm{A}_{1}$ & 31,28 & 1,58 & 4,18 & \\
$\mathrm{~A}_{2}$ & 19,79 & & & \\
$\mathrm{~B}_{1}$ & 34,39 & 1,97 & 4,18 & Homogen \\
$\mathrm{B}_{2}$ & 17,50 & & & \\
\hline
\end{tabular}

Table 4. Summary of Factorial ANAVA Calculation Results 2 × 2

\begin{tabular}{cccccc}
\hline Sources of Variance & $\mathrm{Db}$ & $\mathrm{JK}$ & $\mathrm{RJK}$ & $\mathrm{F}_{\text {hitung }}$ & $\mathrm{F}_{\text {tabel }}$ \\
\hline Between Lines (B) & 1 & 72,60 & 72,60 & 4,75 & 4,01 \\
Between Columns (k) & 1 & 96,27 & 96,27 & 6,29 & 4,01 \\
Interaction & 1 & 552,07 & 552,07 & 36,10 & 4,01 \\
In & 56 & 856,40 & 15,29 & & \\
Reduced Total & 59 & 1577,33 & & & \\
\hline
\end{tabular}

Table 5. Summary of Test Results Using the Tukey Test

\begin{tabular}{cccc}
\hline Group & Qhitung & Qtabel $\alpha=0,05$ & Decision \\
\hline $\mathrm{A}_{1}$ dan $\mathrm{A}_{2}$ & 3,56 & 2,89 & Significant \\
$\mathrm{B}_{1}$ dan $\mathrm{B}_{2}$ & 3,10 & 2,89 & Significant \\
$\mathrm{A}_{1} \mathrm{~B}_{1}$ dan $\mathrm{A}_{2} \mathrm{~B}_{2}$ & 4,68 & 3,67 & Significant \\
$\mathrm{A}_{1} \mathrm{~B}_{1}$ dan $\mathrm{A}_{2} \mathrm{~B}_{1}$ & 8,18 & 3,67 & Significant \\
$\mathrm{A}_{1} \mathrm{~B}_{2}$ dan $\mathrm{A}_{2} \mathrm{~B}_{2}$ & 3,83 & 3,67 & Significant \\
$\mathrm{A}_{1} \mathrm{~B}_{1}$ dan $\mathrm{A}_{1} \mathrm{~B}_{2}$ & 8,51 & 3,67 & Significant \\
$\mathrm{A}_{2} \mathrm{~B}_{1}$ dan $\mathrm{A}_{2} \mathrm{~B}_{2}$ & 3,50 & 3,67 & Not significant \\
\hline
\end{tabular}

Based on the Table 5, there are one of the seven combinations compared to show irrelevant results. It is because there is a significant difference between the average historical learning outcomes learned using conventional models based on visual learning styles and the average historical learning 
outcomes given by using conventional based on auditory learning style. That there is no significant difference between the results of historical learning provided by using the CTL learning model in students who have visual learning styles and students who have auditory learning styles. The results of further testing above shows the interaction between learning models and learning styles on the history learning outcomes of students of SMA 8 Takengon. The interaction of learning models and learning styles can be seen in the Figure 1.

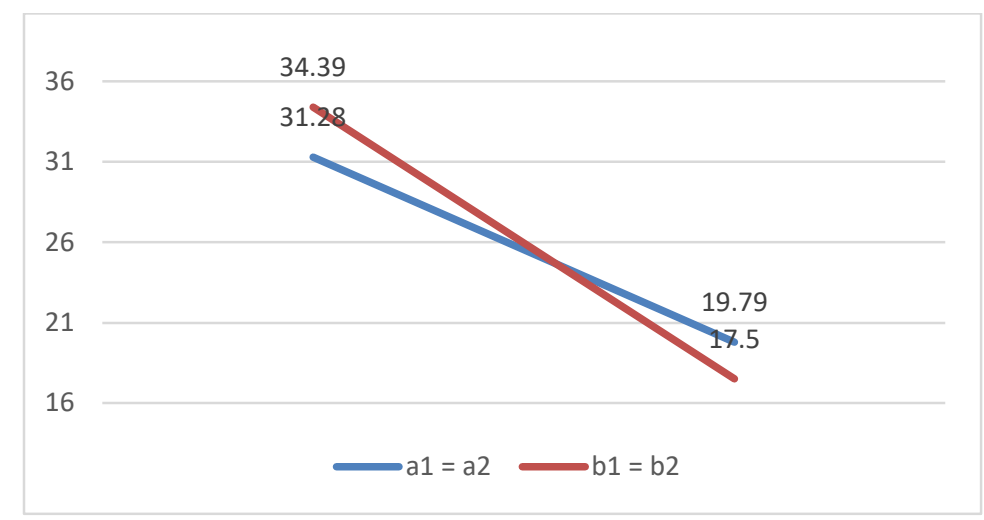

Figure 1. Image of interactions between learning models and learning styles on historical learning outcomes

\section{Disccusions}

The results of the two-path analysis of variance, it is known that $\mathrm{H} 0$, which states the historical learning outcomes of students who use the CTL learning model, is higher than the historical learning outcomes of students who use conventional learning models rejected. Overall there is an influence of CTL and traditional learning models on student history learning outcomes. The results of the analysis using the Tuckey test, the use of the CTL learning model has a very great influence on improving student history learning outcomes. From the results of the research described above, it seems that the CTL learning model shows higher results than conventional learning models. That students who have a visual learning style show that their historical learning outcomes are higher than those of students who have an auditory learning style. Based on the results of the first hypothesis, it knows that the historical learning outcomes of students taught with the CTL learning model are more effective in improving student learning outcomes. It is in line with the results of testing the hypothesis that $t_{\text {count }}>t$ table. There means that Ho rejected it. Thus, the average historical learning outcomes of students taught with the CTL learning model are higher than the average learning outcomes of history taught conventionally. Same with Sriadhi, Gultom, Restu, and Simarmata research (2017) it is advisable to prepare a special exploratory media for high visual ability students, while for students with low visual ability need to do further research to find effective learning media used.

Learning by using the CTL learning model makes a student can provide students with understanding to have the ability to historical events in teaching material. Where the advantage of CTL learning is centered on the student center more practicing and tends not to memorize, in the CTL learning model, these students can work together in achieving a learning goal. Teachers can easily invite students to be more active by using learning models in addition to teaching materials, the internet, and newspapers. Activities in learning taking place in the classroom can be by inviting all active students to pay attention and use the CTL learning model by connecting historical material with real conditions. In the conventional learning model, the learning process only occurs in one direction; students can focus more on the material and teaching material delivered by a teacher. The involvement of a student is only when the teacher gives questions on teaching material. It can happen to some students who have difficulty in developing themselves. The results of the second hypothesis testing show that the historical learning outcomes of students who have a visual learning style are higher than students who have an auditory learning style. The results of hypothesis testing show that $t$ count $>t$ table. It means that Ho rejected it. Thus, the average historical learning outcomes of students 
who have a visual learning style are higher than the average historical learning outcomes of students who have an auditory learning style. Same as Choi-Lundberg, Cuellar, and Williams (2016), however, there were positive correlations between students' cadaveric anatomy question scores with the number and total time of DAVR viewed.

They were providing evidence that the historical learning outcomes of students who have a visual learning style are higher than the history learning outcomes of students who have an auditory learning style. Then the statistical hypothesis is to reject $\mathrm{H} 0$. Where students who have a visual learning style are very active in their efforts to find information related to teaching materials, both using the internet, books, and newspapers. The advantage of visual learning styles is that they are very thorough and remain able to concentrate on classroom situations that are not conducive. In contrast to students who have an auditorial learning style that is students have lacked their adaptation attitudes when the class is in noisy conditions, or students cannot have their concentrate focused on crowded situations. The third hypothesis testing results show that the interaction effect between the use of learning models and learning styles on learning outcomes. The results of the hypothesis show that $t_{\text {count }}>t_{\text {table. }}$. It means that Ho rejected it. It can conclude that there is an interaction between the use of learning models and learning styles on learning outcomes.

The results of this test indicate that there is an interaction effect using the learning model with student learning styles on student history learning outcomes. The results of the Tuckey test, H0, were rejected. Where $\mathrm{H} 0$ there is no influence between learning models with learning styles on student history learning outcomes and $\mathrm{H} 1$, there is an influence between learning models with learning styles on student history learning outcomes. The selection of a teacher's learning model and understanding of student learning styles is necessary for every teacher where the CTL learning model interact with student learning styles. Its namely visual learning styles and auditory learning styles so that it can have an essential influence on the student's historical learning outcomes. Kozub's (2010) success of the different instruction modules measures by an online test over the material presented in the modules and the result shows that student satisfaction with the instruction modules determined by an online survey assessing the participants' reactions to the modules. The major research question is whether the students' different learning styles impacted the learning of the materials in the based instruction modules assessed concerning the students' final grade in the lecture course.

The selection of a teacher's learning model and understanding of student learning styles is necessary for every teacher where the CTL learning model and CTL learning model interact with student learning styles. Namely, visual learning styles and auditory learning styles so that it can have an important influence on the student's historical learning outcomes. The fourth hypothesis testing results show that the history of learning outcomes of students. They taught with CTL learning models that have visual learning styles are more effective than students who taught with conventional learning models that have visual learning styles. The results of hypothesis testing show that $t_{\text {count }}>t_{\text {table. }}$. It means that Ho rejected it. Thus, the average historical learning outcomes of students taught with the CTL model who has a visual learning style are higher than students who trained with a conventional learning model that has a visual learning style.

It following the characteristics of students who have a visual learning style can activate their abilities in learning, besides group discussions, to be able to understand the material provided so that the learning outcomes obtained by them are higher. Students who have a visual learning style with a learning model have differences with conventional methods. This result can know from the way a teacher does the learning process as a whole. Hence, students with visual learning styles are very likely to get boring because they are not able to develop their abilities optimally in absorbing learning material. Students with a visual learning style, in general, like to read and have verbal abilities very quickly. The selection of the CTL learning model very much helps in developing the learning process of students who have a visual learning style. Results of the fifth hypothesis testing show that the historical learning outcomes of students who taught with the CTL learning model that have auditory learning styles are less effective than conventional learning models that have auditory learning styles. The results of hypothesis testing show that $t_{\text {count }}>t_{\text {table. }}$. It means that Ho rejected it. Thus, the average historical learning outcomes of students taught with the CTL learning model that has an auditory learning style are lower than students who taught with a conventional learning model that has an auditory learning style. 
Students with auditory learning styles have higher learning outcomes when given using conventional learning models. In the conventional learning model, students can receive teaching material directly from a teacher where students take notes if deemed necessary and allowed them to ask a teacher's explanation if it is not understood. Students with an auditory learning style need the assertiveness of a teacher because one of their characteristics is that they are easily distracted by noise and experience disturbances in learning when the class is in noisy conditions. So the role of a teacher is crucial in managing learning, discipline, and conditioning the classroom in learning activities repeatedly. The results of the sixth hypothesis testing show that the historical learning outcomes of students taught with the CTL learning model who has a visual learning style are more effective than students who taught with the CTL learning model that has an auditory learning style.

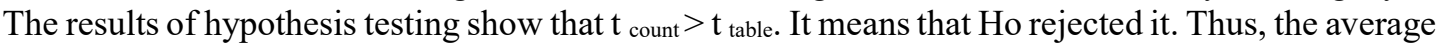
historical learning outcomes of students taught with the CTL learning model who has a visual learning style are higher than students who taught with CTL learning who have an auditory learning style. The CTL learning model is a model that helps teachers link material that taught with real-world situations and encourage students to make connections between the knowledge they have and their application in their lives. The CTL learning model can assist students in being active in finding teaching materials to improve their abilities and be useful for these students. However, the CTL learning model cannot run well if students only receive teaching material from a teacher.

For students who have an auditory learning style, the use in the CTL learning model has less effect on their learning outcomes. It because one of the characteristics of students who have an acoustic learning style is that they prefer to listen to the explanation of a teacher to be able to receive teaching material from the teacher using the learning model conventional. It, according to Martin \& Ertzberger (2013) that was conducted on data obtained from the achievement post-test and on the attitude survey results for the Likert type items (items 1-12). Analyses on achievement and attitude data revealed significant positive differences. The CBI treatment achieved positive post-test scores on the post-test, while the iPad/iPod treatments had positive attitudes. This study has implications for those designing and implementing mobile learning.

The results of the seventh hypothesis testing show that the historical learning outcomes of students who have a visual learning style using conventional learning models are lower than students who have an auditory learning style provided using conventional learning models. Hypothesis testing results show $t_{\text {count }}<t_{\text {table. }}$. It means that Ho rejected it. The conventional learning model is a one-way learning model. Then students can only communicate with the teacher. For students with visual learning styles, the use of conventional learning models does not attract their interest in learning because it is considered less useful in learning and in their lives, where there are summaries in textbooks that make them bored in learning. Whereas for students who have an auditorial learning style, conventional learning models are more appropriate because students can listen to explanations from the teacher. Where the teacher gives a direct focus of their attention and still listen to the explanation of a teacher who feels they are complete enough to meet the learning needs of a student.

According to the research Fadillah, Dewi, Ridho, Majid, and Prastiwi (2016), the lesson study analysis showed the results of $71.09 \%$ at the first lesson and $88.28 \%$ at the second lesson. It means that there is increasing adherence to the indicators after two lessons. Based on the above results, it can be concluded that the result of studying the chemistry of the students of class XI of Senior High School of Sunggal TA 2014/2015 taught by a CTL model based on Lesson Study with Mind Mapping media was higher $(72.88 \%)$ than those taught by conventional learning models $(68.97 \%)$ in the subject matter of colloids System. Similar to Mulyanto, Gunarhadi, and Indriayu research (2018), which examines the effectiveness of the CTL method in mathematics learning, there are significant differences in mathematics learning outcomes between students who take the Problem Based Learning model to the conventional model. Based on research conducted by Setiawati, Ramadhan, and Gani (2018), it knew that the learning model of contextual learning and learning affects the writing skills of fairy tale texts. Fairytale text writing skills taught by students with contextual learning and learning models have better motivation to learn than fairytale text writing skills taught by students with highly motivated direct learning models. Meanwhile, relevant to Agustiya, Sunarso, and Haryani (2017), here is the difference between student learning outcomes in 
the teaching and learning process through CTL using Monopoly media and student learning outcomes in teaching and learning without monopoly media.

\section{CONCLUSION}

This study intended to examine the socio-economic and health harms and benefits associate with khat chewing. Accordingly, 397 khat chewers were randomly selected, and the survey conducted. Moreover, FGDs and key informant interviews were undertaken to collect qualitative information. It supplements the quantitative information from the survey study. The findings of the study indicated that Khat chewing has profound socio-economic and health consequences on the chewers. To mention a few of its negative economic consequences, khat chewers exposed to unnecessary expenses to the extent that it compromised the fulfillment of the basic needs of their families. Due to expenses of khat and the associated substances consumed during and after khat chewing, respondents revealed that their ability to save a particular part of their daily income for difficult times is severely affected. As khat chewing requires them a long time, and it followed with exhaustiveness, respondents also frequently failed to be punctual and absent from work. This made the conflict with their bosses. Apart from these, khat chewing associated with smoking cigarettes and alcohol drinking, which exacerbates the economy of its users due to high expenses and low saving resulted from khat chewing. As khat production has been expanding at the expense of other crops cultivation, this will have its own negative effects on the future production and productivity of the community. Finally, the search for money to buy khat and its associate addiction behaviors such as smoking cigarettes and drinking alcohol have been influencing some of the users to engage in antisocial behaviors such as theft and robbing.

Even though khat has numerous economic and social harms, it will continue to be produced and consumed among the community because there is no consensus among the consumers, the producers, the experts, the government, and the community at large concerning the harms associate with khat chewing. The consumers, experts, and the community argue that khat has several economic and social harms. In contrast, the producers and the government body argues that khat is one of the major cash crops, which is the source of revenue for many producers, distributors, and the nation. The producers and concerned government bodies further argue that there are no empirical evidencebased harms of khat. Thus, attempts made to reduce khat use will remain to be controversial and dilemmatic until the concerned actors reach consensus about the negative consequences and take actions to reduce its harms.

\section{REFERENCES}

Agustiya, F., Sunarso, A., \& Haryani, S. (2017). Influence of ctl model by using monopoly game media to the students' motivation and science learning outcomes. Journal of Primary Education, 6(2), 114-119. doi: https://doi.org/10.15294/jpe.v6i2.17559

Choi-Lundberg, D. L., Cuellar, W. A., \& Williams, A. M. M. (2016). Online dissection audio-visual resources for human anatomy: Undergraduate medical students' usage and learning outcomes. American Association of Anatomists, 9(6), 545-554. doi: https://doi.org/10.1002/ase.1607

DePorter, B., \& Hernacki, M. (2002). Quantum learning: Membiasakan belajar nyaman dan menyenangkan. (Terj. Alwiyah Abdurrahman). Bandung: Kaifa.

Fadillah, A., Dewi, N. P. L. C., Ridho, D., Majid, A. N., \& Prastiwi, M. N. B. (2017). The effect of application of contextual teaching and learning (CTL) model-based on lesson study with mind mapping media to assess student learning outcomes on chemistry on colloid systems. In International Journal of Science and Applied Science: Conference Series (Vol. 1, No. 2, pp. 101-108).

Fadillah, A., Dewi, N. P. L. C., Ridho, D., Majid, A. N., \& Prastiwi, M. N. B. (2017). The effect of application of contextual teaching and learning (CTL) model-based on lesson study with 
mind mapping media to assess student learning outcomes on chemistry on colloid systems. International Journal of Science and Applied Science: Conference Series, 1(2), 101-108. doi: https://doi.org/10.20961/ijsascs.v1i2.5128

Gagne, R. M. (1975). Essentials of learning for instruction. Dryden Press.

Gufron, R., \& Riswanita, R. S. (2012). Gaya belajar kajian teoritik. Yogyakarta: Pustaka Pelajar.

Hamalik, O. (2010). Proses belajar mengajar. Jakarta: Bumi Aksara.

Hartoto, T. (2016). Model Pembelajaran Kooperatif Tipe Group Investigation (GI) Meningkatkan Aktivitas dan Hasil Belajar Sejarah. HISTORIA: Jurnal Program Studi Pendidikan Sejarah, 4(2), 131-142. Doi: http://dx.doi.org/10.24127/hj.v4i2.553

Kindarto, S., \& Gafur, A. (2014). Pembelajaran kontekstual dengan strategi react berbantuan media untuk meningkatkan aktivitas dan hasil belajar IPS. Harmoni Sosial: Jurnal Pendidikan IPS, 1(2), 213-230. Doi: https://doi.org/10.21831/hsjpi.v1i2.2442

Kozub, R. M. (2010). An ANOVA analysis of the relationships between business students' learning styles and effectiveness of web based instruction. American Journal of Business Education, $3(3), 89-98$.

Latipah, E. D. P., \& Afriansyah, E. A., (2018). Analisis kemampuan koneksi matematis siswa menggunakan pendekatan pembelajaran CTL dan RME. Jurnal Teori dan Terapan Matematika. Doi: https://doi.org/10.29313/jmtm.v17i1.3691

Martin, F., \& Ertzberger, J. (2013). Here and now mobile learning: An experimental study on the use of mobile technology. Computers \& Education, 68, 76-85. doi: https://doi.org/10.1016/j.compedu.2013.04.021

Muhlisin, A. (2012). Pengembangan perangkat pembelajaran IPA terpadu berbasis Contextual Teaching and Learning (CTL) dengan model pembelajaran kooperatif tipe Student Teams Achievement Division (STAD) tema polusi udara. Journal of Research and Educational Research Evaluation, 1(2), 139-145.

Mulyanto, H., Gunarhadi, G., \& Indriayu, M. (2018). The effect of problem based learning model on student mathematics learning outcomes viewed from critical thinking skills. International Journal of Educational Research Review, 3(2), 37-45. doi: https://doi.org/10.24331/ijere.408454

Murtiani, M., Fauzan, A., \& Ratnawulan, R. (2012). Penerapan pendekatan Contextual Teaching and Learning (CTL) berbassis lesson study dalam meningkatkan kualitass pembelajaran fisika di SMP Negeri Kota Padang. Jurnal Penelitian Pembelajaran Fisika, 1(1), 1-21. Doi: https://doi.org/10.1234/jppf.v1i1.597

Puji, R. P. N., \& Ahmad, A. R. (2015). Gaya belajar dan kemahiran pemikiran sejarah dalam pembelajaran sejarah di peringkat Universitas. Jurnal Ilmu Pendidikan dan Pengajaran, 2(3), 253-263. Doi: https://doi.org/10.17509/edusentris.v2i3.178

Rahman, A. A., \& Yanti, S. (2016). Pengaruh gaya belajar terhadap hasil belajar siswa pada mata pelajaran IPS terpadu di kelas VII SMP Negeri 1 Peudada. Jurnal Pendidikan Almuslim, $4(2), 1-6$.

Sabri, A. 2010. Strategi belajar mengajar micro teaching. Quantum Teaching.

Sanjaya, W. (2007). Strategi pembelajaran: Berorientasi standar proses pendidikan. Jakarta: Kencana Prenada Media.

Setiawati, N. K., Ramadhan, S., \& Gani, E. (2018, December). The effect of contextual teaching and learning model and motivation towards skill of fable text writing. Paper presented at International Conference on Language, Literature, and Education (ICLLE 2018). Atlantis Press. doi: https://doi.org/10.2991/iclle-18.2018.14 
44 - Harmoni Sosial: Jurnal Pendidikan IPS

Sihono, T. (2004). Contextual Teaching and Learning (CTL) sebagai model pembelajaran ekonomi dalam KBK. Jurnal Ekonomi dan Pendidikan, 1(1), 63-83. Doi: https://doi.org/10.21831/jep.v1i1.673

Sriadhi, S., Gultom, S., Restu, R., \& Simarmata, J. (2018, July). The effect of tutorial multimedia on the transformator learning outcomes based on the students' visual ability. IOP Conference Series: Materials Science and Engineering, 384(1).

Syah, M. (2011). Psikologi pendidikan dengan pendekatan baru. Bandung: Remaja Rosdakarya. 